\title{
Effect of Corporate Financial Leverage on Financial Performance: A Study on Publicly Traded Manufacturing Companies in Bangladesh
}

\author{
Ripon Kumar Dey ${ }^{1}$, Syed Zabid Hossain ${ }^{2} \&$ Rashidah Abdul Rahman ${ }^{3}$ \\ ${ }^{1}$ IBS, University of Rajshahi, Bangladesh \\ ${ }^{2}$ Department of Accounting and Information Systems, University of Rajshahi, Bangladesh \\ ${ }^{3}$ Department of Economics, King Abdulaziz University, Jeddah, Saudi Arabia \\ Correspondence: Rashidah Abdul Rahman. E-mail: rabdulwahid@kau.edu.sa
}

Received: October 27, 2018

Accepted: November 7, $2018 \quad$ Online Published: November 29, 2018

doi:10.5539/ass.v14n12p124

URL: https://doi.org/10.5539/ass.v14n12p124

\begin{abstract}
The study strives to examine the effect of financial leverage on financial performance in a developing country context using two OLS regression models based on panel data consisting of 816 cases (48 companies x 17 years). Financial performance is measured using ROA, ROE, EPS, and Tobin's Q, and financial leverage is measured using the debt-assets ratio and debt-equity ratio. It is observed that ROA and Tobin's Q are negatively correlated with financial leverage, which is in line with the assumptions of the pecking order theory, market timing theory, and many empirical studies. However, financial leverage has a positive effect on ROE and no effect on EPS. These results are also consistent with the MM theorem, static trade off theory and many other empirical studies. Yet again, the two OLS models have put forward conflicting results while taking EPS as the dependent variable. The results corroborate the inefficient use of debt capital and suggest the need to improve the reliability of accounting information.
\end{abstract}

Keywords: financial leverage, financial performance, Bangladesh

\section{Introduction}

Corporate financial managers should set their capital structure in such a way as to minimize the cost of capital and thereby maximize the value of the firm. This is a crucial decision for business entities because managers strive to select the most appropriate debt-equity mix from different levels of financial leverage. Managers who are astute enough to identify and deploy the appropriate mix of debt and equity are amply rewarded (Gleason et al., 2000). Usually financial leverage has a positive effect on firm value because leverage enhances the efficiency and performance of firms (Ghosh, 2007). Firms with higher leverage are mostly inclined to improve their performance (Weill, 2008). However, higher leverage usually leads to higher agency costs because of the diverging interests between shareholders and debt holders. Thus, leverage may be negatively associated with performance (Jensen \& Meckling, 1976; Myers, 1977). The results of empirical research indicate that firm performance is higher when it avoids debt and operates on equity (Vatavu, 2015). The literature provides conflicting arguments concerning the relationship between financial leverage and financial performance. Further, there is still disagreement regarding the influencing factors of optimal capital structure decisions among companies in Bangladesh. In the absence of consensus concerning the optimal capital structure, it is pertinent to investigate the effect of financial leverage on firm performance. Against the above backdrop, this study strives to investigate the impact of financial leverage on the financial performance of publicly traded manufacturing companies in Bangladesh.

\section{Literature Review and Hypotheses Development}

In corporate finance, capital structure decisions are the most debated issue among academics and practitioners, a debate that started from the seminal work of Modigliani and Miller in 1958. They stated that a firm's value is independent of its capital structure decision, by assuming unrealistic assumptions of the real world; such as no corporate taxes, no transaction cost, and a perfect capital market (Modigliani \& Miller, 1958). Later, in 1963, they reviewed their earlier position by incorporating tax benefit (tax-shield) as a determinant of capital structure. They proposed that firms should use the highest amount of debt capital to maximize their value (Modigliani \& Miller, 1963). After the work of Modigliani and Miller, several theories have been developed to explain the 
optimal capital structure. In the agency cost theory, the use of debt in the capital structure augments the agency costs. Agency costs take place as a result of the conflicting interests between the stockholders and managers, as well as between the debt-holders and stockholders. However, greater leverage diminishes the agency costs of outside equity and increases firm value by encouraging managers to act in the interests of the stockholders (Jensen \& Meckling, 1976). According to the static trade-off theory, there is an optimal capital structure that derives from matching the benefits of tax by using debt against the costs associated with debt, such as bankruptcy or financial distress. This theory assumes a positive relationship between financial leverage and financial performance (Myers, 1984). The pecking order theory states that there is no specific target capital structure for firms, and that managers prefer internal financing over external financing and debt over equity whenever external funding is unavoidable; managers also prioritize short-term debt over long-term debt (Myers, 1984).The free cash flows theory argues that firms seek to maintain perilously high levels of debt because they believe these high levels will increase value, despite the threat of financial distress (Myers, 2001). The market timing theory states that low levered companies are those that raise funds when their market valuations are high, while high levered firms are those that raise funds when their market valuations are low. Thus, firms with low leverage are expected to be of high value (Baker \& Wurgler, 2002).

Many empirical studies have been undertaken to determine whether any relationship exists between firm performance and financial leverage, which have produced assorted results. The study conducted by Hasan and Gupta (2013) using a simple regression model for the pooled data of selected public companies in Bangladesh during the period 2005-2009, considered debt ratio as the independent variable and EPS as the dependent variable. The results of the study revealed that leverage has a statistically significant effect on shareholders' return and that appropriate management of leverage can maximize EPS. The study of Chesang and Ayuma (2016) regarding the effect of financial leverage on financial performance using a sample of 66 firms listed on the Nairobi Securities Exchange, found that the debt to equity ratio has a statistically significant impact on financial performance. Similar results were observed in the study of Nduka and Ucheahara (2016). An empirical study was conducted by Abor (2005) to investigate the relationship between the capital structure and profitability of listed firms on the Ghana Stock Exchange for a period of six years from 1998 to 2003. The results showed a significant positive association between the ratio of total debt to total assets and return on equity. The findings of the study of Berger and di Patti (2006) on capital structure and firm performance revealed that leverage could affect the agency costs and thereby influence firm performance. The study also found that higher leverage or lower equity capital ratio is associated with higher profit efficiency and that the effect is both economically and statistically significant. Another research on the impact of the liability-asset ratio on profitability in China's industrial state-owned enterprises by Holz (2002) disclosed that an increase in the liability-asset ratio could allow profitable investment to be realized and thus implied an increase in the volume of profit. A high liability ratio could also encourage better external supervision with positive effects on profit.

Quang and Xin (2014) conducted an empirical study on the impact of the capital structure on the financial performance of the nonfinancial firms listed in Vietnam between2009 and 2012. The results showed that capital structure has a statistically significant negative effect on financial performance measured by ROA and ROE. Using a Jordanian setting, Zeitun and Tian (2007) observed a negative relationship between the level of capital structure and performance in both the accounting and market measures. Majumdar and Chhibber (1999) also identified a negative relationship between the capital structure and performance of a large cross-section of Indian firms. Weill (2008) found a negative and non-significant relationship between leverage and corporate performance in Italy and Portugal, respectively. Using three accounting measures of financial performance (i.e., return on equity, return on assets, and gross profit margin) on a sample of Egyptian nonfinancial listed firms from 1997 to 2005, El-Sayed Ebaid (2009) found that, in general terms, the capital structure decision has a weak-to-no impact on firm performance. Similarly, no relationship was observed between profitability and capital structure by Fosberg and Ghosh (2011) in their research on AMEX and NYSE firms.

The results of empirical research on the association between capital structure and firm performance of Malaysian listed companies by Salim and Yadav (2012) indicated that firm performance, measured by return on assets (ROA), return on equity (ROE), Tobin's Q, and earnings per share (EPS), has a negative affiliation with short-term debt (STD), long-term debt (LTD), and total debt (TD) as independent variables. The study also used size and growth as control variables. The study of Saeedi and Mahmoodi (2011) concerning the relationship between financial leverage and financial performance used four performance measures (return on assets, return on equity, earnings per share, and Tobin's Q) as dependent variables and three capital structure measures (long-term debt, short-term debt, and total debt ratios) as independent variables. The investigation was performed using panel data of a sample of 320 companies listed on the Tehran Stock Exchange (TSE) over a 
period of 8 years (2002-2009). The results indicated that firm performance, measured by EPS and Tobin's Q, is significantly and positively associated with capital structure; however, there is a negative relationship between capital structure and ROA. Moreover, the study found no significant relationship between ROE and capital structure.Based on the capital structure theories (agency cost theory and static trade off theory) and the findings of the reviewed empirical research, the following hypotheses have been developed to test the validity of the above theories and studies using Bangladesh as the setting.

$\mathrm{H}_{1}$ : Financial leverage has a positive and significant effect on return on assets (ROA).

$\mathrm{H}_{2}$ : Financial leverage has a positive and significant effect on return on equity (ROE).

$\mathrm{H}_{3}$ : Financial leverage has a positive and significant effect on earnings per share (EPS).

$\mathrm{H}_{4}$ : Financial leverage has a positive and significant effect on the Tobin's $\mathrm{Q}$ ratio ( $\mathrm{Q}$ ratio).

\section{Methodology}

\subsection{Sample}

According to the Dhaka Stock Exchange (DSE) data base, as of December 31, 2017, there are twelve manufacturing sectors in the Bangladesh Capital Market containing one hundred and seventy-five companies. This list is used as the sampling frame for the present study. Fifty percent or six out of the twelve industrial sectors are selected using the simple random sampling technique and a study period of seventeen years ranging from 2001 to 2017 is considered adequate to generalize the results of the study. The companies listed on the DSE under the selected industrial sectors in or before 2001 are included in the sample, resulting in 49 (forty-nine) companies. We exclude one company because of the non-availability of an annual report during the whole study period; thus, resulting in 48 companies as the final sample.

\subsection{Variable Measurement}

As we are investigating the impact of financial leverage on financial performance, the former is the independent variable and the latter is the dependent variable. In our study, we use three repeatedly used accounting-based performance measures (ROA, ROE and EPS) and the mixed based measure Tobin's Q to assess the firm's financial performance, as shown in Table 1.

Table 1. Summary of variable measures

\begin{tabular}{|c|c|c|c|c|}
\hline Main variable & Type & Proxies & Acronyms & Formula \\
\hline \multirow{4}{*}{ Financial performance } & \multirow{4}{*}{ Dependent } & Return on Assets & ROA & EBIT/Total Assets \\
\hline & & Return on Equity & ROE & EAT/Total Equity \\
\hline & & Earnings Per Share & EPS & EAT/No. of Share \\
\hline & & Tobin’s Q Ratio & Q Ratio & Total Market Value of Firm/Total Assets Value \\
\hline \multirow{2}{*}{ Financial leverage } & \multirow{2}{*}{ Independent } & Debt to assets ratio & DA & Total liabilities/ Total assets \\
\hline & & Debt to equity ratio & $\mathrm{DE}$ & Total liabilities/ Total equity \\
\hline \multirow{3}{*}{ Influential } & \multirow{3}{*}{ Control } & Firm Size & FS & Natural Logarithm of Book Value of Total Assets \\
\hline & & Sales Growth & SG & Sales $_{t}-$ Sales $_{t-1} /$ Sales $_{t-1}$ \\
\hline & & Assets Turnover & AT & Sales/ Total Assets \\
\hline
\end{tabular}

This study uses total debt to total assets and total debt to equity fund as measures of financial leverage. We focus on total debt (or total liabilities) rather than short-term debt or long-term debt in order to follow the principal aim of this research, and, as such, the study focuses on the total liabilities in general. Most of the capital structure theories use long-term debt as the proxy for leverage. However, we use total debt as the proxy for leverage following empirical studies (Ahmad, Salman, \& Shamsi, 2015; Rouf, 2015) because the Bangladesh Bond Market is yet to establish itself, and the main source of debt financing is commercial banks, which do not encourage long-term loans. Moreover, the implicit cost of current liabilities is recognized in financial management.

Based on previous studies, we also incorporate three control variables - firm size, sales growth, and assets turnover- that may influence a firm's financial performance.

\subsection{Models'Specification}

The panel data methodology is used to test the influence of financial leverage on the financial performance of the listed manufacturing companies on DSE. Pool observations are collected from the published annual reports of the selected companies. The general regression model of the panel data is given as: 


$$
\begin{gathered}
\mathrm{Y}_{i t}=\beta_{0}+\beta_{1} \mathrm{X}_{1}+\beta_{2} \mathrm{X}_{2}+\ldots+\beta_{\mathrm{k}} \mathrm{X}_{\mathrm{k}}+\varepsilon_{\mathrm{it}} \\
i=1 \ldots \ldots \ldots \ldots \ldots 48, \quad t=1 \ldots \ldots \ldots \ldots 15
\end{gathered}
$$

Where, the subscript $i$ denotes the cross-sectional measurement. Subscript $t$ stands for the time-series. $Y_{i t}$ stands for the dependent variable in the model (ROA, ROE, EPS, Q Ratio). $\mathrm{B}_{0}$ is the intercept; $\beta_{1}, \beta_{2} \ldots \ldots . . . \beta_{\mathrm{k}}$ are the regression slopes or coefficients for the independent variables, $\mathrm{X}_{1}, \mathrm{X}_{2, \ldots \ldots} \mathrm{X}_{\mathrm{k}}$ are the independent variables, and $\varepsilon_{i t}$ is the error term.

Once we have converted the above general least squares model into our specified variables, the same is shown in Table 2.

\begin{tabular}{|c|c|}
\hline \multicolumn{2}{|l|}{ Model \#1 } \\
\hline$(\mathrm{ROA})_{\mathrm{it}}=\mathrm{b}_{\mathrm{o}}+\mathrm{b}_{1}(\mathrm{DA})_{\mathrm{it}}+\mathrm{b}_{2}(\mathrm{FS})_{\mathrm{it}}+\mathrm{b}_{3}(\mathrm{SG})_{\mathrm{it}}+\mathrm{b}_{4}(\mathrm{AT})_{\mathrm{it}}+\varepsilon_{\mathrm{it}}$ & (2) \\
\hline$(\mathrm{ROE})_{\mathrm{it}}=\mathrm{b}_{\mathrm{o}}+\mathrm{b}_{1}(\mathrm{DA})_{\mathrm{it}}+\mathrm{b}_{2}(\mathrm{FS})_{\mathrm{it}}+\mathrm{b}_{3}(\mathrm{SG})_{\mathrm{it}}+\mathrm{b}_{4}(\mathrm{AT})_{\mathrm{it}}+\varepsilon_{\mathrm{it}}$ & (3) \\
\hline$(E P S)_{i t}=b_{o}+b_{1}(D A)_{i t}+b_{2}(F S)_{i t}+b_{3}(S G)_{i t}+b_{4}(A T)_{i t}+\varepsilon_{i t}$ & (4) \\
\hline$(\mathrm{Q} \text { Ratio })_{\mathrm{it}}=\mathrm{b}_{\mathrm{o}}+\mathrm{b}_{1}(\mathrm{DA})_{\mathrm{it}}+\mathrm{b}_{2}(\mathrm{FS})_{\mathrm{it}}+\mathrm{b}_{3}(\mathrm{SG})_{\mathrm{it}}+\mathrm{b}_{4}(\mathrm{AT})_{\mathrm{it}}+\varepsilon_{\mathrm{it}}$ & (5) \\
\hline \multicolumn{2}{|l|}{ Model \#2 } \\
\hline$(\mathrm{ROA})_{\mathrm{it}}=\mathrm{b}_{\mathrm{o}}+\mathrm{b}_{1}(\mathrm{DE})_{\mathrm{it}}+\mathrm{b}_{2}(\mathrm{FS})_{\mathrm{it}}+\mathrm{b}_{3}(\mathrm{SG})_{\mathrm{it}}+\mathrm{b}_{4}(\mathrm{AT})_{\mathrm{it}}+\varepsilon_{\mathrm{it}}$ & (6) \\
\hline$(\mathrm{ROE})_{\mathrm{it}}=\mathrm{b}_{\mathrm{o}}+\mathrm{b}_{1}(\mathrm{DE})_{\mathrm{it}}+\mathrm{b}_{2}(\mathrm{FS})_{\mathrm{it}}+\mathrm{b}_{3}(\mathrm{SG})_{\mathrm{it}}+\mathrm{b}_{4}(\mathrm{AT})_{\mathrm{it}}+\varepsilon_{\mathrm{it}}$ & (7) \\
\hline$(E P S)_{i t}=b_{o}+b_{1}(D E)_{i t}+b_{2}(F S)_{i t}+b_{3}(S G)_{i t}+b_{4}(A T)_{i t}+\varepsilon_{i t}$ & (8) \\
\hline$(\mathrm{Q} \text { Ratio })_{\mathrm{it}}=\mathrm{b}_{\mathrm{o}}+\mathrm{b}_{1}(\mathrm{DE})_{\mathrm{it}}+\mathrm{b}_{2}(\mathrm{FS})_{\mathrm{it}}+\mathrm{b}_{3}(\mathrm{SG})_{\mathrm{it}}+\mathrm{b}_{4}(\mathrm{AT})_{\mathrm{it}}+\varepsilon_{\mathrm{it}}$ & (9) \\
\hline
\end{tabular}

Table 2. Regression models

\section{Empirical Results}

In this section we show the data analysis and interpretation of the empirical results. The descriptive statistics are presented for understanding the nature of data and the correlation matrix for the variables is reported in order to examine the relationships that exist among the variables. The regression results for the panel data for each of the performance measures are displayed and thoroughly discussed for the period 2001 to 2017. The analyses are used to test the earlier formulated hypotheses to establish the relationships that exist among the variables.

\subsection{Descriptive Statistics}

Table 3. Descriptive statistics

\begin{tabular}{cccccccc}
\hline Variables & Obs. & Min. & Max. & Mean & Median & Std. Dev. & $\begin{array}{c}\text { Normality } \\
\text { P values }\end{array}$ \\
\hline DA & 816 & 0.03 & 1.37 & 0.58 & 0.57 & 0.23 & $\mathrm{p}<.05^{*}$ \\
DE & 816 & -51.10 & 36.49 & 2.07 & 1.15 & 6.09 & $\mathrm{p}<.05^{*}$ \\
ROA & 816 & -0.14 & 0.36 & 0.09 & 0.08 & 0.08 & $\mathrm{p}<.05^{*}$ \\
ROE & 816 & -279.63 & 252.16 & 11.03 & 9.26 & 31.87 & $\mathrm{p}<.05^{*}$ \\
EPS & 816 & 9.46 & 23.06 & 17.21 & 16.85 & 1.44 & $\mathrm{p}<.05^{*}$ \\
Q Ratio & 816 & 0.45 & 3.94 & 1.26 & 1.17 & 0.41 & $\mathrm{p}<.05^{*}$ \\
FS & 816 & 2.63 & 11.47 & 6.73 & 6.65 & 1.50 & $\mathrm{p}<.05^{*}$ \\
ATO & 816 & 00 & 2.73 & 0.90 & 0.81 & 0.59 & $\mathrm{p}<.05^{*}$ \\
SG & 816 & 1.00 & 2.48 & 1.45 & 1.45 & 0.12 & $\mathrm{p}<.05^{*}$ \\
\hline
\end{tabular}

*Deviation from normality is significant at $\mathrm{p}<.05$.

Note: Transformation Functions

Transformed EPS $=$ Square root of (Original EPS + 263)

Transformed Tobin's $\mathrm{Q}=$ Square root of original Tobin's $\mathrm{Q}$

Transformed SG $=$ Square root of $($ Original SG +2 )

Table 3 provides a summary of descriptive statistics of all the variables of the sample firms. The financial leverage measured by debt assets ratio (DA) reveals a mean of 58 percent and a median of 57 percent with standard deviation of 23 percent. These results suggest that about 60 percent of total assets of the sample firms are financed through debt capital. This result, thus, suggests that the firms are being operated with high level of financial leverage. Another measure of financial leverage is debt equity ratio (DE), which has a mean of 207 percent and a median of 115 percent. Like DA ratios, these values indicate that on an average the debt financing 
is higher as compared to equity financing in the firms. These outcomes are consistent with the study findings of Alom (2013).

The proxy of financial performance, ROA has a mean of 9 percent and a median of 8 percent with standard deviation of 8 percent, and minimum and maximum value of -14 percent and 36 percent respectively. The positive ROA suggests that the sample firms were on average profitable, although some firms were being operated at a loss which is reflected in the negative minimum observed value of ROA. If the average inflation rate is taken into consideration, the picture suggests a poor financial performance and inefficiency of management in using assets of the firms during the study period.

The mean (median) of ROE, EPS and Tobin's Q are 11.03 (9.26) percent, 17.21 (16.85) and 1.26 (1.17) times respectively. Their standard deviations are 31.87 percent, 1.44 and 0.41 times respectively. These results reveal the same financial performance scenario which is indicated by ROA.

\subsection{Correlation of the Variables}

To assess the effect of financial leverage on financial performance, Pearson's correlation analysis is used to determine the magnitude and direction of associations. It is evident from Table 4 that the correlation coefficients of the associations of DA, an indicator of financial leverage, with the financial performance indicators, ROA, ROE, EPS, and Tobin's Q, are $-0.211,0.169,0.118$, and -0.114 , respectively. Hence, DA has a significant negative relationship with ROA and Tobin's Q. These results are consistent with the study findings of Chowdhury and Chowdhury (2010) in terms of both magnitude and the direction of associations. However, the results are somewhat lower in magnitude than the value of the correlation coefficient found by Rouf (2015). The magnitudes of the associations are, however, weaker than expected. As indicated by the correlation coefficients, DA has a significant positive relationship with ROE and EPS. The indicator of financial leverage, DE, has almost the same relationship, in terms of both magnitude and direction, as the performance measures.

Table 4. Pearson correlation matrix among the variables

\begin{tabular}{llllllllll}
\hline Variables & DA & DE & ROE & ROA & EPS & Q Ratio & FS & AT & SG \\
\hline Debt Assets Ratio & 1 & & & & & & & & \\
Debt Equity Ratio & $0.672^{* *}$ & 1 & & & & & & & \\
Return on Equity & $0.169^{* *}$ & $0.215^{* *}$ & 1 & & & & & & \\
Return on Assets & $-0.211^{* *}$ & $-0.085^{*}$ & $0.649^{* *}$ & 1 & & & & & \\
EPS & $0.118^{* *}$ & $0.098^{*}$ & $0.449^{* *}$ & $0.412^{* *}$ & 1 & & & & \\
Tobin's Q & $-0.114^{* *}$ & $-0.099^{* *}$ & $0.374^{* *}$ & $0.469^{* *}$ & $0.201^{* *}$ & 1 & & & \\
Firm Size & $-0.210^{* *}$ & 0.048 & $0.215^{* *}$ & $0.210^{* *}$ & $0.234^{* *}$ & 0.015 & 1 & & \\
Assets Turnover & $0.094^{* *}$ & $0.080^{*}$ & $0.440^{* * *}$ & $0.453^{* *}$ & $0.310^{* *}$ & $0.356^{* *}$ & 0.007 & 1 & \\
Sales Growth & 0.060 & 0.071 & $0.241^{* *}$ & $0.255^{* *}$ & $0.131^{* *}$ & 0.070 & $0.100^{* *}$ & $0.238^{* *}$ & 1 \\
\hline
\end{tabular}

** Correlation is significant at the 0.01 level (2-tailed).

*Correlation is significant at the 0.05 level (2-tailed).

Again, a weak negative association is observed between the financial leverage proxy, DA, and the control variable, firm size (-0.21), which is significant at the 0.01 level, while a very weak positive association is observed between DA and assets turnover, a control variable (0.094), which is significant at the 0.01 level. As the value of the correlation coefficient is 0.06 , there is a very weak and statistically insignificant positive relationship between DA and the sales growth of the sample companies. There is hardly any relationship between $\mathrm{DE}$ and any of the control variables as is evident from the correlation coefficients. However, all three control variables have statistically significant positive correlations with all four measures of financial performance.

As shown in Table 4, all the independent variables are free from serious multicollinearity, and, hence, suitable for regression analysis.

\subsection{Regression Results}

The ordinary least squares (OLS) regression results of the estimation of the panel data models with each of the financial performance measures are displayed in Tables 5 and 6 . As different financial leverage proxies, DA and $\mathrm{DE}$, are used as the predictor variables in Model1 and Model 2, respectively, we analyze the results in two parts.

\subsubsection{Analysis of Results Based on Model 1}

Table 5 shows the results of Modell for testing the effect of financial leverage on financial performance using all 
four measures. When ROA and Tobin's Q are the dependent variables, the regression coefficients of debt ratio are -0.10 and -0.74 , respectively. As the $p$ values are less than 0.05 , the hypotheses are accepted at the $95 \%$ confidence level, thereby indicating that financial leverage has a statistically significant negative effect on ROA and Tobin's Q.

Conversely, when ROE and EPS are used as the dependent variables then the regression coefficients of the debt assets ratio are 8.97 and 13.28 , respectively. Both the $\mathrm{p}$ values are less than 0.05 , and, hence, the hypotheses are accepted at the $95 \%$ confidence level. These results suggest that financial leverage has statistically significant positive effect on ROE and EPS.

Table 5. Multiple Regression Analysis: Financial Leverage (Debt to Total Assets) and Financial Performance

\begin{tabular}{|c|c|c|c|c|c|}
\hline \multirow{2}{*}{$\begin{array}{c}\text { Description } \\
\text { Model Fit }\end{array}$} & \multirow{2}{*}{$\begin{array}{l}\text { Expected } \\
\text { Direction }\end{array}$} & \multicolumn{4}{|c|}{ Dependent Variables } \\
\hline & & ROA & ROE & EPS & Tobin's Q \\
\hline Overall $\mathrm{R}^{2}$ & & 0.362 & 0.332 & 0.173 & 0.156 \\
\hline Adjusted $\mathrm{R}^{2}$ & & 0.358 & 0.328 & 0.167 & 0.151 \\
\hline No. of Observations & & 705 & 658 & 690 & 680 \\
\hline Intercept & & 0.04 & -16.00 & -20.49 & 1.59 \\
\hline \multicolumn{6}{|l|}{ Independent Variable } \\
\hline Debt Assets Ratio & + & $\begin{array}{l}-0.10 \\
(000)\end{array}$ & $\begin{array}{l}8.97 \\
(000)\end{array}$ & $\begin{array}{l}13.28 \\
(.001)\end{array}$ & $\begin{array}{l}-0.74 \\
(000)\end{array}$ \\
\hline \multicolumn{6}{|l|}{ Control Variables } \\
\hline Firm Size & + & $\begin{array}{c}0.01 \\
(000)\end{array}$ & $\begin{array}{l}2.08 \\
(000)\end{array}$ & $\begin{array}{l}3.53 \\
(000)\end{array}$ & $\begin{array}{c}0.01 \\
(.838)\end{array}$ \\
\hline Assets Turnover & + & $\begin{array}{l}0.06 \\
(000)\end{array}$ & $\begin{array}{l}8.51 \\
(000)\end{array}$ & $\begin{array}{l}8.87 \\
(000)\end{array}$ & $\begin{array}{c}0.64 \\
(000)\end{array}$ \\
\hline Sales Growth & + & $\begin{array}{c}0.06 \\
(000)\end{array}$ & $\begin{array}{c}8.30 \\
(.001)\end{array}$ & $\begin{array}{c}3.61 \\
(.442)\end{array}$ & $\begin{array}{l}-0.08 \\
(.712)\end{array}$ \\
\hline
\end{tabular}

Figures in parentheses are $p$ values. ${ }^{*}$ Significant at the $5 \%$ level.

All three control variables in Model 1; namely, firm size, assets turnover, and sales growth, are positively and significantly related to the financial performance irrespective of the measurement technique (ROA, ROE, EPS, and Tobin's Q) at the $5 \%$ level of significance $(p<0.05$, two-tailed). These results are consistent with the empirical results of other researchers, such as Ahmad, Abdullah \& Roslan (2012), and Abor (2007).

4.3.2 Analysis of Results Based on Model 2

Table 6. Multiple Regression Analysis: Financial Leverage (Debt to Equity fund) and Financial Performance

\begin{tabular}{|c|c|c|c|c|c|}
\hline Description & Expected & \multicolumn{4}{|c|}{ Dependent Variables } \\
\hline Model Fit & Direction & ROA & ROE & EPS & Tobin's Q \\
\hline Overall $\mathrm{R}^{2}$ & & 0.324 & 0.333 & 0.160 & 0.146 \\
\hline Adjusted $\mathrm{R}^{2}$ & & 0.320 & 0.329 & 0.154 & 0.141 \\
\hline No. of Observations & & 706 & 673 & 688 & 678 \\
\hline Intercept & & -0.04 & -10.13 & -12.08 & 1.19 \\
\hline Independent Variable & & & & & \\
\hline Debt Equity Ratio & + & $\begin{array}{c}-0.003 \\
(000)\end{array}$ & $\begin{array}{c}0.44 \\
(000)\end{array}$ & $\begin{array}{c}0.17 \\
(.422)\end{array}$ & $\begin{array}{l}-0.04 \\
(.001)\end{array}$ \\
\hline Control Variables & & & & & \\
\hline Firm Size & + & $\begin{array}{l}0.012 \\
(000)\end{array}$ & $\begin{array}{c}1.80 \\
(000)\end{array}$ & $\begin{array}{l}3.271 \\
(000)\end{array}$ & $\begin{array}{c}0.02 \\
(.487)\end{array}$ \\
\hline Assets Turnover & + & $\begin{array}{l}0.057 \\
(000)\end{array}$ & $\begin{array}{c}8.81 \\
(000)\end{array}$ & $\begin{array}{l}8.83 \\
(000)\end{array}$ & $\begin{array}{c}0.63 \\
(000)\end{array}$ \\
\hline Sales Growth & + & $\begin{array}{l}0.069 \\
(000)\end{array}$ & $\begin{array}{c}7.24 \\
(0.002)\end{array}$ & $\begin{array}{c}6.54 \\
(0.164)\end{array}$ & $\begin{array}{c}-0.04 \\
(0.857)\end{array}$ \\
\hline
\end{tabular}

Figures in parentheses are $p$ values. * Significant at the $5 \%$ level.

Table 6 shows the results of Model 2. Using ROA and Tobin's Q as the dependent variables, we obtain the 
regression coefficients of debt equity ratio as -0.003 and -0.04 , respectively. Zero or close to zero $p$ values signal acceptance of the hypotheses at the $95 \%$ confidence level and indicate that financial leverage has a statistically significant negative effect on corporate financial performance when measured by these two tools.

When ROE is used, the regression coefficient of the debt equity ratio is 0.44 and the $p$ value is less than 0.05 .Hence, the hypothesis is accepted at the $95 \%$ confidence level and indicates that financial leverage has a statistically significant positive effect on ROE.

Again, when EPS is used, the $\mathrm{p}$ value is higher than 0.05 , which rejects the hypothesis at the $95 \%$ confidence level and indicates that financial leverage has no statistically significant effect on EPS. Similar toModel1, the three control variables in Model 2; namely, firm size, assets turnover, and sales growth, are positively and significantly related to financial performance in terms of ROA, ROE, EPS, and Tobin's Q at the 5 percent level of significance $(\mathrm{p}<.05$, two-tailed). These results are also consistent with the empirical results of other researchers such as Rouf (2015).

\section{Conclusion}

The study has strived to investigate the effects of financial leverage on the financial performance of manufacturing companies listed on the DSE. The theoretical literature on capital structures, specifically the Modigliani-Miller theorem, pecking order theory, agency cost theory, market timing theory, and some other theories have been reviewed to provide an acceptable understanding of how the use of debt in capital structure can affect a firm's financial performance. A wide-range of related empirical literature has been reviewed to identify the proxies and measurements for financial leverage, financial performance, and different control variables. Following which, we have used four financial performance measures; namely, ROA, ROE, EPS, and Tobin's Q to ensure the robustness of this study. We have used two proxies, DA and DE, for financial leverage to observe whether there is any deviation in test results. As found in most of the literature, the three variables -firm size, assets turnover, and sales growth-that have an influence on a firm's financial performance have been used in this study as control variables to expand our explanatory variables in addition to financial leverage.

From the empirical results, we have found that financial performance - measured by ROA and Tobin's Q- is negatively correlated with financial leverage. This result is consistent with the assumptions of the pecking order theory, in that there is no target capital structure and that the relationship between financial leverage and firm performance is negative. The result is also consistent with the hypothesis that leverage is conversely related to the firm valuation of the market timing theory and many empirical research results; as stated earlier. It also implies the high cost of debt in Bangladesh.

We have also found that financial leverage has a positive effect on financial performance, as measured by ROE and EPS (Model1), which is well-matched with the agency cost theory that assumes that higher leverage reduces the agency costs of outside equity and increases firm value by limiting or encouraging managers to act more in the interests of shareholders. Our finding that leverage has no effect on financial performance measured by EPS (Model2) is consistent with the MM theorem that states that a firm is independent of its capital structure.

In testing hypothesis number three using EPS as the dependent variable; two models have given conflicting results. Model 1 has indicated a positive relationship, while Model 2 has shown no relation between financial leverage and financial performance. EPS and ROE have been calculated using the same accounting information (Numerator), but they have given different results (Model2). These findings imply inefficient financial management in using debt capital and suggest a need for improvement in the reliability of the accounting information. Thus, we are unable to reach any conclusive decision regarding the nature of the impact (or the direction of the relationship) of financial leverage on the financial performance of publicly traded manufacturing companies in Bangladesh.

Despite the important contributions of this study providing indigenous findings regarding the relationship between corporate financial leverage and financial performance in the context of a developing country, there are a number of inherent setbacks in the study. This study does not block the instantaneous effect on corporate performance of any changes in corporate governance structure, such as changes in ownership structure. In addition, the effects of the geographical location of the firms and ongoing global economic downturn during the study period on the capital structure decisions and corporate performance of Bangladeshi firms have not been studied.

\section{References}

Abor, J. (2005). The effect of capital structure on profitability: An empirical analysis of listed firms in Ghana. The Journal of Risk Finance, 6(5), 438-445. https://doi.org/10.1108/15265940510633505 
Abor, J. (2007). Debt policy and performance of SMEs: Evidence from Ghanaian and South African firms. The Journal of Risk Finance, 8(4), 364-379. https://doi.org/10.1108/15265940710777315

Alom, K. (2013). Capital structure choice of Bangladeshi firms: An empirical investigation. Asian Journal of Finance \& Accounting, 5(1), 320. https://doi.org/10.5296/ajfa.v5i1.3495

Ahmad, N., Salman, A., \& Shamsi, A. F. (2015). Impact of Financial Leverage on Firms' Profitability: An Investigation from Cement Sector of Pakistan. Research Journal of Finance and Accounting, 6(7), 75-81.

Ahmad, Z., Abdullah, N. M. H., \& Roslan, S. (2012). Capital structure effect on firm's performance: Focusing on consumers and industrials sectors on Malaysian firms. International review of business research papers, $8(5), 137-155$.

Baker, M., \& Wurgler, J. (2002). Market timing and capital structure. The journal of finance, 57(1), 1-32. https://doi.org/10.1111/1540-6261.00414

Berger, A. N., \& Di Patti, E. B. (2006). Capital structure and firm performance: A new approach to testing agency theory and an application to the banking industry. Journal of Banking \& Finance, 30(4), 1065-1102. https://doi.org/10.1016/j.jbankfin.2005.05.015

Chesang, D., \& Ayuma, C. O. (2016). Effect of Financial Leverage on Profitability of Listed Agricultural Firms at the Nairobi Securities Exchange. International Journal of Economics, Commerce and Management, 4(12), 445-493.

Chowdhury, A., \& Chowdhury, S. P. (2010). Impact of capital structure on firm's value: Evidence from Bangladesh. Business \& Economic Horizons, 3(3). https://doi.org/10.15208/beh.2010.32

El-Sayed Ebaid, I. (2009). The impact of capital-structure choice on firm performance: empirical evidence from Egypt. The Journal of Risk Finance, 10(5), 477-487. https://doi.org/10.1108/15265940911001385

Fosberg, R. H., \& Ghosh, A. (2011). Profitability and capital structure of Amex and Nyse firms. Journal of Business \& Economics Research (JBER), 4(11). https://doi.org/10.19030/jber.v4i11.2714

Ghosh, S. (2007). Leverage, managerial monitoring and firm valuation: A simultaneous equation approach. Research in Economics, 61(2), 84-98. https://doi.org/10.1016/j.rie.2007.03.001

Gleason, K. C., Mathur, L. K., \& Mathur, I. (2000). The interrelationship between culture, capital structure, and performance: Evidence from European retailers. Journal of business research, 50(2), 185-191. https://doi.org/10.1016/S0148-2963(99)00031-4

Hasan, A., \& Gupta, A. (2013). The effect of leverage on shareholders' return: An empirical study on some selected listed companies in Bangladesh. European Journal of Business and Management, 5(3), 46-53.

Holz, C. A. (2002). The impact of the liability-asset ratio on profitability in China's industrial state-owned enterprises. China Economic Review, 13(1), 1-26. https://doi.org/10.1016/S1043-951X(01)00054-2

Jensen, M. C., \& Meckling, W. H. (1976). Theory of the firm: Managerial behavior, agency costs and ownership structure. Journal of financial economics, 3(4), 305-360. https://doi.org/10.1016/0304-405X(76)90026-X

Majumdar, S. K., \& Chhibber, P. (1999). Capital structure and performance: Evidence from a transition economy on an aspect of corporate governance. Public Choice, 98(3), 287-305. https://doi.org/10.1023/A:1018355127454

Modigliani, F., \& Miller, M. H. (1958). The cost of capital, corporation finance and the theory of investment. The American economic review, 48(3), 261-297.

Modigliani, F., \& Miller, M. H. (1963). Corporate income taxes and the cost of capital: A correction. The American economic review, 433-443.

Myers, S. C. (1984). The capital structure puzzle. The Journal of finance, 39(3), 574-592. https://doi.org/10.1111/j.1540-6261.1984.tb03646.x

Myers, S. C. (1977). Determinants of corporate borrowing. Journal of corporate borrowing, 5, 147-175. https://doi.org/10.1016/0304-405X(77)90015-0

Myers, S. C. (2001). Capital structure. The Journal of economic perspectives, 15(2), 81-102. https://doi.org/10.1257/jep.15.2.81

Nduka, A. J., \& Ucheahara, O. F. (2016). Financing Corporate Organization for Efficient Performance in Nigeria: Equity or Debt Option. African Journal of Education, Science and Technology, April, 3(2), 196-204. 
Quang, D., X., \& Xin, W. Z. (2014). The impact of ownership structure and capital structure on financial performance of Vietnamese firms. International Business Research, 7(2), 64. https://doi.org/10.5539/ibr.v7n2p64

Rouf, M. A. (2015). Capital Structure and Firm Performance of Listed Non-Financial Companies in Bangladesh. The International Journal of Applied Economics and Finance, 9(1), 25-32. https://doi.org/10.3923/ijaef.2015.25.32

Saeedi, A., \& Mahmoodi, I. (2011). Capital structure and firm performance: Evidence from Iranian companies. International Research Journal of Finance and Economics, 70(11), 20-29.

Salim, M., \& Yadav, R. (2012). Capital structure and firm performance: Evidence from Malaysian listed

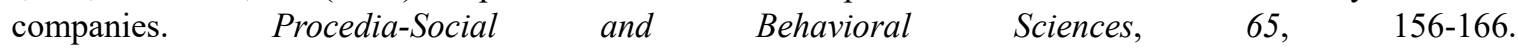
https://doi.org/10.1016/j.sbspro.2012.11.105

Vatavu, S. (2015). The impact of capital structure on financial performance in Romanian listed companies. Procedia Economics and Finance, 32, 1314-1322. https://doi.org/10.1016/S2212-5671(15)01508-7

Weill, L. (2008). Leverage and corporate performance: Does institutional environment matter? Small Business Economics, 30(3), 251-265. https://doi.org/10.1007/s11187-006-9045-7

Zeitun, R., \& Tian, G. G. (2007). Capital structure and corporate performance: Evidence from Jordan. Australasian accounting business \& finance journal, 1(4), 40-61.

\section{Appendix (List of sample companies)}

\begin{tabular}{|c|c|c|}
\hline SL No & Company & Sector \\
\hline 1. & Aramit Cement Ltd. & Cement \\
\hline 2. & Confidence Cement Ltd. & Cement \\
\hline 3. & Heidelberg Cement Bangladesh Ltd. & Cement \\
\hline 4. & Meghna Cement Mills Ltd. & Cement \\
\hline 5. & Aftab Automobiles Ltd. & Engineering \\
\hline 6. & Anwer Galvanizing Ltd. & Engineering \\
\hline 7. & Atlas Bangladesh Ltd. & Engineering \\
\hline 8. & Aziz Pipes Ltd. & Engineering \\
\hline 9. & Bangladesh Auto cars Ltd & Engineering \\
\hline 10. & Bangladesh Lamps Ltd. & Engineering \\
\hline 11. & Bangladesh Thai Aluminium Ltd. & Engineering \\
\hline 12. & Eastern Cables Ltd. & Engineering \\
\hline 13. & Kay \& Que Bangladesh & Engineering \\
\hline 14. & Monno Jute Stafllers Ltd. & Engineering \\
\hline 15. & National Polymer Industries Ltd. & Engineering \\
\hline 16. & National Tubes Ltd. & Engineering \\
\hline 17. & Quasem Drycells Ltd. & Engineering \\
\hline 18. & Rangpur Foundry Ltd. & Engineering \\
\hline 19. & Renwick Jajneswar \& Co. Bd. & Engineering \\
\hline 20. & Singer Bangladesh Ltd. & Engineering \\
\hline 21. & Bangladesh Welding Electrodes Ltd. & Fuel and Power \\
\hline 22. & Chittagong Vegetable Oil Industries Ltd. & Fuel and Power \\
\hline 23 , & Eastern Lubricants Blenders ltd. & Fuel and Power \\
\hline 24. & Linde Bangladesh Ltd. & Fuel and Power \\
\hline 25. & Padma Oil Company Ltd. & Fuel and Power \\
\hline 26. & Jute Spinners Ltd. & Jute \\
\hline 27. & Northern Jute Manufacturing Co. Ltd. & Jute \\
\hline 28. & SonaliAansh Industries Ltd. & Jute \\
\hline 29. & ACI Ltd & Pharmaceuticals \& Chemicals \\
\hline 30. & Ambee Pharmaceuticals Ltd. & Pharmaceuticals \& Chemicals \\
\hline
\end{tabular}




\begin{tabular}{lll}
\hline 31. & Beximco Pharmaceuticals Ltd. & Pharmaceuticals \& Chemicals \\
32. & Beximco Synthetics & Pharmaceuticals \& Chemicals \\
33. & GlaxoSmithKline Bangladesh Ltd. & Pharmaceuticals \& Chemicals \\
34. & Imam Button Industries Ltd. & Pharmaceuticals \& Chemicals \\
35. & The IBN SINA Pharmaceutical Industry Ltd. & Pharmaceuticals \& Chemicals \\
36. & Keya Cosmetics Ltd. & Pharmaceuticals \& Chemicals \\
37. & Kohinoor Chemical Co. (Bd.) Ltd. & Pharmaceuticals \& Chemicals \\
38. & Libra Infusions Ltd. & Pharmaceuticals \& Chemicals \\
39. & Orion Infusion Ltd. & Pharmaceuticals \& Chemicals \\
40. & Pharma Aids Ltd. & Pharmaceuticals \& Chemicals \\
41. & Reckitt Benckiser Bd. Ltd. & Pharmaceuticals \& Chemicals \\
42. & Renata Limited & Pharmaceuticals \& Chemicals \\
43. & Square Pharmaceuticals Ltd. & Pharmaceuticals \& Chemicals \\
44. & Apex Foot Ware Ltd. & Tannery \\
45. & Apex Tannery Ltd. & Tannery \\
46. & Bata Shoe Co. Ltd. & Tannery \\
47. & Legacy Foot ware Ltd. & Tannery \\
48. & Samata Leather Complex Ltd. & Tannery \\
\hline
\end{tabular}

\section{Copyrights}

Copyright for this article is retained by the author(s), with first publication rights granted to the journal.

This is an open-access article distributed under the terms and conditions of the Creative Commons Attribution license (http://creativecommons.org/licenses/by/4.0/). 